\title{
Screening of metallic pollution in complex environmental samples through a transcriptomic fingerprint method
}

\section{Mickael Cregut ( $\square$ mickael.cregut@univ-nantes.fr)}

University of Nantes, Oniris, CNRS, GEPEA, UMR 6144, F-85000 La Roche sur yon

https://orcid.org/0000-0002-2779-4475

Anna Hua

University of Nantes, Oniris, CNRS, GEPEA, UMR 6144, F-85000 La Roche sur yon

\section{Sulivan Jouanneau}

University of Nantes, Oniris, CNRS, GEPEA, UMR 6144, F-85000 La Roche sur yon

\section{Ali Assaf}

University of Nantes, Oniris, CNRS, GEPEA, UMR 6144, F-85000 La Roche sur yon

Christophe BY Cordella

INRA-AgroParisTech/INRA914 PCNA

\section{Gérald Thouand}

University of Nantes, Oniris, CNRS, GEPEA, UMR 6144, F-85000 La Roche sur yon

\section{Marie-José Durand}

University of Nantes, Oniris, CNRS, GEPEA, UMR 6144, F-85000 La Roche sur yon

\section{Research Article}

Keywords: Bioassays, bioreporter, biosensor, environmental pollutants, ecotoxicity assessment, metals, transcriptome profiling

Posted Date: July 6th, 2021

DOl: https://doi.org/10.21203/rs.3.rs-172595/v1

License: (c) (i) This work is licensed under a Creative Commons Attribution 4.0 International License. Read Full License

Version of Record: A version of this preprint was published at Environmental Science and Pollution Research on August 3rd, 2021. See the published version at https://doi.org/10.1007/s11356-021-155453. 


\section{Abstract}

Characterizing waste ecotoxicity is labourious because of both the undefined nature of environmental samples and the diversity of contaminants that can be present. With regard to these limitations, traditional approaches do not provide information about the nature of the pollution encountered. To improve such assessments, a fluorescent library of 1,870 transcriptomic reporters from E. coli K12 MG1655 was used to report the ecotoxic status of environmental samples. The reliability of the approach was evaluated with 6 metallic pollutants ( $\mathrm{As}, \mathrm{Cu}, \mathrm{Cd}, \mathrm{Hg}, \mathrm{Pb}, \mathrm{Zn}$ ) used alone and in mixture in pure and complex matrices. A total of 18 synthetic samples were used to characterize the specificity of the resulting metallic contamination fingerprints. Metallic contamination impacted 4.5 to $10.2 \%$ of the whole transcriptomic fingerprint of E. coli. The analysis revealed that a subset of 175 transcriptomic reporters is sufficient to characterize metallic contamination, regardless of the nature of the sample. A statistical model distinguished patterns due to metallic contamination and provided information about the level of toxicity with $93-98 \%$ confidence. The use of the transcriptomic assessment was validated for 17 complex matrices with various toxicities and metal contaminants, such as activated sludge, wastewater effluent, soil, wood and river water. The presence of metals and their associated toxicity, which seems linked to their bioavailabilities, were thereby determined. This method constitutes a possible tool to screen unknown complex samples for their metallic status and identify those for which a deeper characterization must be achieved by the use of traditional biosensors and analytical methods.

\section{Introduction}

Annually, 76.8 million tons of hazardous waste is treated in Europe (Eurostat, 2020). Waste processing is mainly recycling (36.4\%), landfilling (33.9\%) and incineration (7.7\% and 5.9\% with and without energy recovery, respectively) (Eurostat, 2020). To choose a treatment for hazardous wastes, the EU2008/98/EC directive requires a global characterization including an assessment of the risk they pose to the environment (Directive (EC), 2008). Methods for environmental risk assessment were compiled in Hazard Property-14 (HP-14), which enables a classification of wastes in terms of environmental impact (Pandard and Römbke, 2013). This classification impacts waste treatment processes, such as incineration for dangerous wastes or recycling and reuse for safer wastes.

To characterize waste safety, 2 main strategies can be used. A mathematical modelling approach can be performed, but this strategy requires information about the compounds present in the waste (Directive EC, 1999; Hennebert et al., 2013). The second strategy is dedicated to undefined wastes of unknown composition, for which an experimental procedure employing bioassays must be undertaken to clarify their environmental impact (Council Regulation EC, 2008). For the latter approach, the recommended bioassays are those based on different trophic levels (producers, consumers and decomposers), and the use of many tests is proposed to report on acute and/or chronic toxicity, such as those based on fishes, microcrustaceans, microorganisms (bacteria and microalgae), earthworms or duckweed (Council Regulation EC, 2017). In France, the National Institute for Industrial Environment and Risks (Ineris) nd chronic tests, to establish the HP-14 property 
in accordance with the literature (Pandard et al., 2006). These bioassays inform about the global toxicity but do not describe the nature of the toxicity, which can be crucial information in choosing a reprocessing strategy to reuse waste.

Identifying pollutant(s) responsible for a toxic effect is technically achievable in a simple liquid matrix through physico-chemical analyses. For wastes, which are generally complex mixtures of chemicals, this assessment is unfair, because the total amount of a pollutant can be radically disconnected from its bioavailable fraction (Kaag et al., 1998; Vig et al., 2003). Moreover, other constituents present in the matrix can alter its toxicity, notably due to synergistic or antagonistic effects (Cedergreen; 2014). In such matrices, bioavailable molecules such as metals or organic contaminants and their toxicity can be identified with the use of recombinant bioassays (Ivask et al., 2002; Jouanneau et al., 2011; Hua et al., 2015; Martin-Betancor et al., 2015). The bioassays are based on recombinant strains engineered to report the fraction of pollutants likely to cause a toxic effect, such as their bioavailable fractions. The presence of the pollutant induces the emission of a specific signal which can be bioluminescent, fluorescent, chemical or electric in nature (D'Souza 2001; Belkin 2003; van der Meer and Belkin 2010; Xu et al. 2013). Recombinant bioassays have been largely used to detect metallic compounds in the environment (Wong et al. 1995; Ivask et al. 2002; Trang et al. 2005; Gueuné et al. 2009). However, their development is limited because it requires the identification of resistance genes in response to the presence of a specific pollutant. Moreover, their use requires also complex statistical analyses to overcome the lack of specificity of reporting strains (Ben-Israel et al. 1998; Jouanneau et al. 2011).

The use of bioassays for ecotoxicological risk assessment remains arduous with complex mixtures such as industrial waste because of the diversity of pollutants encountered, their presence in mixtures and the possible interactions that can occur within the matrix. Ecotoxicological assessment tools identifying the types of pollutants present and their quantities would be of particular interest in waste management.

In the last few years, many studies have applied whole-genome transcriptomics analyses to assess the toxicity of chemicals (Zhang et al. 2011; Su et al. 2011; 2013). Such analyses are based on the assumption that a specific contaminant provokes a unique gene expression pattern in the cell. This concept was validated by Elad et al. (2015), who identified 5 classes of pollutants from 25 toxic compounds with a genome-wide bacterial bioreporter array. To date, the environmental reliability of the approach needs to be confirmed for complex matrices, such as waste and environmental samples, where the presence of many constituents can potentially alter gene expression profiles and decrease the usefulness of the approach.

Hence, this work aims to assess the possibility of exploiting gene expression profiling to identify pollution associated with metals in complex environmental matrices. For this task, the use of the whole-genome transcriptomic analysis of E. coli K12 MG1655 was first validated as a bioassay to report the presence of contaminants in pure matrices. Statistical analyses have allowed us to discriminate transcriptomic reporters responsible for specific metal fingerprints that were thereafter used to analyse complex samples tn detert metallir rontamination in envirnnmental and waste samples. Validation of this screening Loading [MathJax]/jax/output/CommonHTML/fonts/TeX/fontdata.js 
methodology to detect metallic pollution was performed with the use of analytical methods for the total fraction and the use of bioassays for the bioavailable fraction. The present study was conducted not only to scientifically complement the relevant previous works but also to provide a tool to industries involving complex matrix evaluations.

\section{Material And Methods}

\section{Metal standards used in this study}

The metals used in this study were arsenic $\left(\mathrm{As}_{2} \mathrm{O}_{3}\right.$, Sigma Aldrich, 311383; purity: > 99.95\%), copper (CuSO $5 \mathrm{H}_{2} \mathrm{O}$, Sigma Aldrich, 209198; purity: > 98\%), mercury $\left(\mathrm{HgCl}_{2}\right.$, Honeywell Fluka, 215465; purity: $\geq$ 99.5\%), cadmium ( $\mathrm{CdCl}_{2} 2.5 \mathrm{H}_{2} \mathrm{O}$, Sigma Aldrich, 529575; purity: > 99.99\%), lead $\left(\mathrm{Pb}\left(\mathrm{CH}_{3} \mathrm{COO}\right)_{2} 3 \mathrm{H}_{2} \mathrm{O}\right.$, Panreac, 131466.1210; purity: > 99.95\%) and zinc ( $\mathrm{ZnCl}_{2}$, Sigma Aldrich, 229997; purity: $>$ 99.99\%). Metals were solubilized in distilled water in accordance with good laboratory practices, with an adjusted $\mathrm{pH}$ enabling their complete solubilization.

\section{Environmental and synthetic samples used to validate the approach}

\section{Description of the samples}

A total of 35 samples was used in this study. Eighteen synthetic samples were produced with known concentrations of metal dissolved in deionized water. In addition, 17 complex samples from diverse origins, including environmental samples and wastes, were also used in this study. They originated from river, soil, sediment, wood and chemical industries (effluent and sludge) (Table 1).

Table 1: Description of samples

\begin{tabular}{|c|c|c|c|c|c|}
\hline $\begin{array}{l}\text { Type of } \\
\text { sample }\end{array}$ & Nature & $\begin{array}{l}\text { Number of } \\
\text { samples }\end{array}$ & Description & $\begin{array}{l}\text { Physical } \\
\text { state }\end{array}$ & Origin \\
\hline Synthetic & $\begin{array}{l}\text { Distilled } \\
\text { water }\end{array}$ & $3 \times 6$ & $\begin{array}{l}\text { Single contamination of } 6 \text { metals (arsenic, copper, } \\
\text { mercury, cadmium, zinc and lead) at } 3 \text { concentrations } \\
\text { (C1, } C 2 \text { and } C 3 \text { ) }\end{array}$ & Liquid & $\begin{array}{l}\text { Produced at the laboratory with water fom a purification } \\
\text { system (Elix 3, Millipore, } \mathrm{Fr} \text { ) }\end{array}$ \\
\hline Complex & River & $1+3$ & $\begin{array}{l}1 \text { natural river water sa mple without metal addition and } 3 \\
\text { niver sample contaminated with copper and cadmium }\end{array}$ & Liquid & $\begin{array}{l}\text { Sampled fom the Yon river (Pays de la Loire; Fr) at GPS } \\
\text { location: } 46.676493,-1.408744\end{array}$ \\
\hline Complex & Sediment & 2 & commercial samples & Solid & $\begin{array}{l}\text { Commercial origin, referen ces NCS DC } 73 \text { 022; NCD DC } 73 \\
317 \mathrm{~A} \text { (Techlab, Fr) }\end{array}$ \\
\hline Complex & Sludge & 2 & $\begin{array}{l}1 \text { commercial sample } \\
1 \text { industrial treatment }\end{array}$ & Solid & $\begin{array}{l}\text { Commercial origin. References CRMO09 (SigmaAldrich, Fr) } \\
\text { Industrial waste collected from Sol lay Tavaux (Fr) }\end{array}$ \\
\hline Complex & Effuent & 3 & Wastewater treatment Plant & Liquid & Industrial effuent collected fom Sol vey Tavaux (Fr) \\
\hline Complex & Soil & 2 & Unknown samples collected fom a conteminated site & Solid & $\begin{array}{l}\text { Environmental soils contaminated by anthro pic activities given } \\
\text { with the courtesy of the Greenation society }(\mathrm{Fr})\end{array}$ \\
\hline Complex & Wood & 4 & Unknown samples wastes & Solid & $\begin{array}{l}\text { Wood samples grinded at } 500 \mu \mathrm{m} \text {, containing } 2 \text { uncharacterized } \\
\text { samples and } 2 \text { artificially contaminated samples (Fr) }\end{array}$ \\
\hline
\end{tabular}

\section{Pretreatment for solid samples}


Prior to the analysis, a leaching step was undertaken for solid matrices (i.e., soil, wood, sediment and sludge) as follows: $20 \mathrm{~g}$ of dried sample was shaken at $200 \mathrm{rpm}$ in $200 \mathrm{~mL}$ of distilled water $(\mathrm{pH}=6.5$, at room temperature) in a $1 \mathrm{~L}$ polyethylene terephthalate bottle (Grosseron, Fr). After 24 hours of shaking (200 rpm), the leachate was centrifuged twice $(6,000 \mathrm{~g}, 5 \mathrm{~min})$ to withdraw suspended particles (Foucault et al., 2013).

\section{Bacterial strains used in this study}

In this study, two kinds of bacterial strains were used: bioluminescent strains, enabling biodetection of metals, and fluorescent strains, reporting changes in the transcriptomic profile of E. coli (Table 2).

Table 2

Bacterial strains used in this study

\begin{tabular}{|c|c|c|c|c|}
\hline Name & $\begin{array}{l}\text { Type of } \\
\text { response }\end{array}$ & Plasmid & $\begin{array}{l}\text { Antibiotic } \\
\text { resistance }\end{array}$ & Reference \\
\hline \multicolumn{5}{|l|}{ Bioluminescent strains } \\
\hline E. coli DH1 pBtaclux & Constitutive & pBtaclux & $a m p^{R}$ & $\begin{array}{l}\text { Jouanneau et al., } \\
2011\end{array}$ \\
\hline E. coli K12 MG1655 pBarslux & Inducible & pBarslux & $a m p^{R}$ & $\begin{array}{l}\text { Jouanneau et al., } \\
2011\end{array}$ \\
\hline E. coli K12 MG1655 pBcoplux & Inducible & pBcoplux & $a m p^{R}$ & $\begin{array}{l}\text { Jouanneau et al., } \\
2011\end{array}$ \\
\hline E. coli K12 MG1655 pBmerlux & Inducible & pBmerlux & $a m p^{R}$ & $\begin{array}{l}\text { Jouanneau et al., } \\
2011\end{array}$ \\
\hline E. coli K12 MG1655 pBzntlux & Inducible & pBzntlux & $a m p^{R}$ & $\begin{array}{l}\text { Jouanneau et al., } \\
2011\end{array}$ \\
\hline \multicolumn{5}{|l|}{ Fluorescent strains } \\
\hline $\begin{array}{l}\text { 1,870 strains (host: E.coli K12 } \\
\text { MG1655) }\end{array}$ & Inducible & pMSs201 & $\operatorname{kan}^{\mathrm{R}}$ & $\begin{array}{l}\text { Zaslaver et al., } \\
2006\end{array}$ \\
\hline
\end{tabular}

\section{Preparation of bioluminescent strains to report bioavailable metals}

The bioluminescent strains used in this study were E. coli DH1 pBtaclux, E. coli K12 MG1655 pBarslux, $E$. coli K12 MG1655 pBcoplux, E. coli K12 MG1655 pBzntlux and E. coli K12 MG1655 pBmerlux (Charrier et al., 2011; Jouanneau et al., 2011). The use of this panel enabled the identification and semi- 
(Jouanneau et al., 2011). Bioluminescent strains were cultivated to prepare ready-to-use microplates to quantify the bioavailable fractions of metals. Bioluminescent strains were cultivated for $16 \mathrm{~h}$ in acetate medium at $30^{\circ} \mathrm{C}$ at $250 \mathrm{rpm}$. Acetate medium was prepared in distilled water at $2.835 \mathrm{~g} \cdot \mathrm{L}^{-1} \mathrm{CH}_{3} \mathrm{COONa \bigotimes}$ $3 \mathrm{H}_{2} \mathrm{O}$ (Sigma Aldrich, 32318-M), 0.1919 g.L ${ }^{-1} \mathrm{NH}_{4} \mathrm{Cl}$ (Sigma Aldrich, 09718), $0.028 \mathrm{~g} \cdot \mathrm{L}^{-1} \mathrm{~K}_{2} \mathrm{HPO}_{4}$ (Dutscher, 471787-CER), $5 \mathrm{~g} . \mathrm{L}^{-1} \mathrm{NaCl}$ (Labogros, 9020401), $0.5 \mathrm{~g} . \mathrm{L}^{-1}$ yeast extract (Biokar Diagnostics, A1202HA), $0.1 \mathrm{~g} . \mathrm{L}^{-1}$ tryptone (Biokar Diagnostics, A1401HA) and $100 \mu \mathrm{g} \cdot \mathrm{mL}^{-1}$ ampicillin (Sigma Aldrich, A9518). The final pH of the medium was fixed at 6.8 (Charrier et al. 2011). Following a precultivation step, inducible cells were diluted in fresh acetate medium to an optical density of 0.2 at $620 \mathrm{~nm}(0.2$ $\left.\mathrm{OD}_{620 \mathrm{~nm}}\right)$. Strains were grown at $30{ }^{\circ} \mathrm{C}$ until $0.45 \mathrm{OD}_{620 \mathrm{~nm}}$. The $E$. coli pBtaclux strain was diluted in fresh acetate medium to $0.075 \mathrm{OD}_{620 \mathrm{~nm}}$ and cultivated until $0.18 \mathrm{OD}_{620 \mathrm{~nm}}$. Thereafter, it was recovered by centrifugation $\left(6000 \mathrm{~g}, 10 \mathrm{~min}, 4^{\circ} \mathrm{C}\right)$ and diluted V/V with a saccharose solution $\left(240 \mathrm{g.L}{ }^{-1}\right)$ to 0.075 $\mathrm{OD}_{620 \mathrm{~nm}}$. White 96-well microplates (Thermo Scientific Nunc, 136101, Fr) were filled with $100 \mu \mathrm{L}$ of the diluted suspension and frozen for $3 \mathrm{~h}$ at $-80^{\circ} \mathrm{C}$, afterwards the frozen preparation was lyophilized at $-56^{\circ} \mathrm{C}$ at $0.05 \mathrm{mbar}$ with a Christ Alpha 1-2 instrument (Grosseron, $\mathrm{Fr}$ ) for $36 \mathrm{~h}$. At the end of the lyophilization process, the microplates were sealed with aluminium foil (Dutscher, 106570, Fr) and stored at $-20^{\circ} \mathrm{C}$ for months until use.

\section{Preparation of a fluorescent library of 1,870 strains}

A library of 1,870 fluorescent strains targeting all the promoters in E. coli K12 MG1655 was purchased from Dharmacon (https://horizondiscovery.com/). Each bacterial strain bears a recombinant plasmid pMSs201 that possesses a transcriptional fusion between one $E$. coli promoter inserted upstream of the fluorescent gfpmut2 gene reporter (Zaslaver et al., 2006). In addition, two strains without a promoter upstream of the gfpmut2 gene were used as controls in this study: E. coliK12 MG1655 pMSs201_U66 and E. coliK12 MG1655 pMSs201_U139. The fluorescent strains were cultivated to prepare long-term storage suspensions. For this, $100 \mu \mathrm{L}$ of each fluorescent strain was cultivated for $16 \mathrm{~h}$ in 96 -well microplates at $37^{\circ} \mathrm{C}$ in $100 \mu \mathrm{L}$ of HEPES medium, whose composition was $10 \mathrm{~g} . \mathrm{L}^{-1}$ tryptone (Biokar Diagnostics, A1401 HA, Fr), 5 g.L ${ }^{-1} \mathrm{NaCl}$ (Labogros, 9020401, Fr), 2 g.L ${ }^{-1}$ glucose (Sigma Aldrich, 16301, $\mathrm{Fr}), 11.9 \mathrm{~g} . \mathrm{L}^{-1} \mathrm{HEPES}$ (Sigma Aldrich, $\mathrm{H} 3375, \mathrm{Fr}$ ) and $25 \mu \mathrm{g} \cdot \mathrm{mL}^{-1}$ kanamycin in distilled water. The final $\mathrm{pH}$ of the medium was 6.8 (Elad et al., 2013). At the end of the incubation, $100 \mu \mathrm{L}$ of $50 \%$ glycerol was added to the suspension, and the microplates were sealed with aluminium foil and kept at $-80{ }^{\circ} \mathrm{C}$ until use (Dominique Dutscher, 106570, Fr).

\section{Ecotoxicological assessment with bacterial bioassays}

\section{Growth inhibition bioassay to determine the intrinsic toxicity of the 6 metals used in this study}

As a preliminary experiment, growth inhibition assays were performed in the presence of metals in synthetic medium to quantify their toxicity. This analysis was performed to define the effective concentrations of metals used in this study. For this task, the growth of E. coli K12 MG1655 nMSc3n1 1166 and $F$ colik12 MG1655 nMSc3n1 11130 strains was measured in the presence of Loading [MathJax]/jax/output/CommonHTML/fonts/TeX/fontdata.js 
increasing concentrations of a reference metal. The cell concentration was adjusted to $0.05 \mathrm{OD}_{620 \mathrm{~nm}}$ in HEPES base medium, and the cells were incubated at $37^{\circ} \mathrm{C}$ for $20 \mathrm{~h}$ with $200 \mathrm{rpm}$ agitation in transparent 96-well microplates (Greiner, 0220035, Fr). Bacterial growth was monitored using a SPECTROstar Nano reader (BMG Labtech, $\mathrm{Fr}$ ). Dose response curves were established from the growth rate measured during the exponential growth phase. For each metal, the effective concentrations C1, C2 and C3 were determined using REGTOX Macro version 7.0.7 (Vindimian, REGTOX) (Figure S1, Supplemental Section). Concentration $\mathrm{C} 1$ corresponds to the highest tested concentration with no observed effect (NOEC for no observed effect concentration). Concentration $\mathrm{C} 2$ was defined as the lowest observed effect concentration (LOEC), and concentration C3 was the effective concentration for $25 \%$ effect $\left(\mathrm{EC}_{25}\right)$.

\section{Bioassay of bioluminescent strains to assess the toxicities of complex samples}

The overall toxicities of the samples were assessed using a E. coli DH1 strain carrying the pBtaclux plasmid using the method described by Charrier et al. (2011) and Jouanneau et al. (2011). The global toxicity of the sample was inversely proportional to the luminescence emitted by the strain after one hour of exposure. Briefly, $100 \mu \mathrm{L}$ of reconstituted freeze-dried bacteria was treated with $25 \mu \mathrm{L}$ of a toxicant for one hour at $30{ }^{\circ} \mathrm{C}$. The bioluminescence was integrated for $1 \mathrm{sec}$ at $30^{\circ} \mathrm{C}$ with a Microlumat Plus LB96V luminometer (Berthold, $\mathrm{Fr}$ ). The inhibition rate for bioluminescent strains $\left(\mathrm{IR}_{\mathrm{B}}\right)$ was calculated (Eq. 1).

eq $1 \mathrm{IR}_{\mathrm{B}}=1-\frac{\mathrm{RLU}_{\text {toxicant }}}{\mathrm{RLU}_{\text {control }}}$.

with $I R_{B}$ as the inhibition rate and RLU as the level of bioluminescence in relative light units.

Bioassay of bioluminescent strains to quantify bioavailable metals

Metal semi-quantification was assessed with bioluminescent strains (Table 2). To perform metal semiquantification, freeze-dried bioluminescent strains were hydrated 30 min with $100 \mu \mathrm{L}$ of distilled water $\left(30{ }^{\circ} \mathrm{C}\right)$. Thereafter, $25 \mu \mathrm{L}$ of sample was added, and the mixture was incubated for one hour at $30^{\circ} \mathrm{C}$. The bioluminescence was integrated with a Microlumat Plus LB96V luminometer for $1 \mathrm{sec}$ at $30^{\circ} \mathrm{C}$ (Berthold, $\mathrm{Fr})$. The induction ratio ( $\left(\mathrm{IndR}_{\mathrm{B}}\right)$ for inducible strains was calculated (Eq. 2).

eq $2 \operatorname{IndR}_{\mathrm{B}}=\frac{\mathrm{RLU}_{\text {assay }}}{\mathrm{RLU}_{\text {control }}}$

with IndR ${ }_{B}$ as the induction ratio and $R L U$ as the level of bioluminescence in the relative light units.

A control experiment was performed with distilled water. Metal quantification ( $\mathrm{As}, \mathrm{Cu}, \mathrm{Hg}$ and $\mathrm{Cd}$ ) was carried out using Metalsoft software, the bioluminescence emitted by the 4 metallic strains and that emitted by E. coli DH1 pBtaclux (Jouanneau et al., 2011).

Bioassay using the fluorescent strain library to characterize toxicity of complex samples 
The response of the library was compared in the presence and absence of toxicants in both synthetic and environmental samples. Frozen 96-well microplates containing the fluorescent library were thawed and cultivated overnight at $37^{\circ} \mathrm{C}$ in HEPES medium. Following cultivation, strain suspensions were diluted $(1 / 10)$ to a final volume of $100 \mu \mathrm{L}$ in HEPES medium in black 96 -well microplates with transparent flat bottoms (Dutscher, 655090, Fr). The suspension was incubated for $2 \mathrm{~h}$ to allow bacterial growth up to 0.3 $\mathrm{OD}_{620 \mathrm{~nm}}$ before the addition of $25 \mu \mathrm{L}$ of toxicant. After $3 \mathrm{~h}$ of incubation, fluorescence ( $485 \mathrm{~nm}$ excitation/535 nm emission) and absorbance $\left(\mathrm{OD}_{620 \mathrm{~nm}}\right)$, measurements were performed by a Spark $10 \mathrm{M}$ reader (Tecan, $\mathrm{Fr})$. The induction ratio $\left(\mathrm{IndR}_{\mathrm{F}}\right)$ for fluorescent strains was calculated as follows (Eq. 3): The activity of the tested transcript was defined as repressed when the $I n d R_{F}$ value was in $[-\infty, 0.5]$ and activated when the $\operatorname{IndR}_{F}$ value was in $[2,+\infty]$. Finally, values were normalized in $[-100,0]$ and $[0,+100]$ for repression and activation, respectively.

$$
\left(\frac{\mathrm{RFU}}{\mathrm{OD}_{620 \mathrm{~nm}}} \text { teststrain }-\frac{\mathrm{RFU}}{\mathrm{OD}_{620 \mathrm{~nm}}} \text { promoterlessstrains }\right)_{\text {toxiccondition }}
$$

Eq. $3 \operatorname{IndR}_{\mathrm{F}}=\frac{}{\left(\frac{\mathrm{RFU}}{\mathrm{OD}_{620 \mathrm{~nm}}} \text { teststrain }-\frac{\mathrm{RFU}}{\mathrm{OD}_{620 \mathrm{~mm}}} \text { promoterlessstrains }\right)_{\text {controlcondition }}}$

with IndR ${ }_{F}$ as the induction ratio for f/uorescent strains, RFU as the intensity of fluorescence in relative fluorescence units and $O D_{620 \mathrm{~nm}}$ as the optical density at $620 \mathrm{~nm}$. The toxic condition was compared to a control condition, which was incubated in the presence of distilled water. The term test strain refers to a fluorescent reporter strain, and the promoterless strains are both E. coli MG1655 pMSs201_U66 and E. coli MG1655 pMSs201_U139.

\section{Analytics and statistical analyses}

Concentrations of metals natively present in environmental samples were measured by ICP-MS by a certified laboratory (LEAV, Vendée, Fr).

Statistical analyses were performed on the results obtained from the fluorescent strain library with MATLAB software version 2012b using the Statistics toolbox and the SAISIR® package (Cordella and Bertrand 2014). Statistical analyses were based on principal component analysis (PCA), followed by factorial discriminant analysis (FDA) from SAISIR®. FDA was calculated using the first 10 principal component scores. A discriminant model was calculated using a cross-validation procedure. The model was calculated by random selection with $2 / 3$ of the database, and the last $1 / 3$ was used for the crossvalidation procedure. The final classification rate corresponded to the average of 100 iterations.

\section{Results}

\section{Toxicity of reference metals and effective concentrations}




\section{Determination of the effective concentrations}

The growth inhibition produced by increasing the concentration of the 6 metals was modelled by logistic regression analyses to define the toxic concentrations referring to $\mathrm{C} 1, \mathrm{C} 2$ and $\mathrm{C} 3$ concentrations, which corresponded to the NOEC, LOEC and $\mathrm{EC}_{25}$, respectively (Figure S1, Supplementary Information). Among the six tested metals, mercury was the most toxic, with an LOEC value of $2.5 \mu \mathrm{M}$. For this metal, $\mathrm{EC}_{25} \mathrm{was}$ reached quickly, at a concentration of $2.65 \mu \mathrm{M}$. Arsenic, lead and cadmium possessed similar levels of toxicity, with LOECs of $505 \mu \mathrm{M}, 525 \mu \mathrm{M}$ and $650 \mu \mathrm{M}$, respectively. Zinc showed intermediate toxicity between arsenic and mercury. Finally, copper was the least toxic, with an NOEC and LOEC of $250 \mu \mathrm{M}$ and $1,405 \mu \mathrm{M}$, respectively (Table 3).

Table 3

Metal concentration thresholds inducing a toxic effect for E.coli MG1655 pMSs201_U139 and E.coliMG1655 pMSs201_U66. Metals concentrations are expressed in $\mu \mathrm{M}$

\begin{tabular}{|llllllll|}
\hline \multirow{2}{*}{ Threshold } & Acronym & \multicolumn{6}{l|}{ Metal concentration $(\mu \mathrm{M})$} \\
\cline { 3 - 8 } & & Arsenic & Zinc & Lead & Copper & Cadmium & Mercury \\
\hline NOEC & C1 & 25 & 25 & 25 & 250 & 2.5 & 0.25 \\
\hline LOEC & C2 & 505 & 250 & 525 & 1,405 & 650 & 2.5 \\
\hline EC $_{25}$ & C3 & 1,015 & 300 & 1,320 & 1,450 & 905 & 2.65 \\
\hline
\end{tabular}


Table 4

Number of regulated transcripts depending on the nature and the concentration of the metal $(\mathrm{C} 1, \mathrm{C} 2$ and C3)

\begin{tabular}{|c|c|c|c|c|c|}
\hline Metal & C1 & C2 & C3 & $\begin{array}{l}\text { Total number of } \\
\text { regulated transcripts per } \\
\text { metal (*) }\end{array}$ & $\begin{array}{l}\text { Number of overlapping transcripts } \\
\text { between metallic concentrations }\end{array}$ \\
\hline Arsenic & $\begin{array}{l}20 \\
(1.1 \%)\end{array}$ & $\begin{array}{l}32 \\
(1.8 \%)\end{array}$ & $\begin{array}{l}32 \\
(1.8 \%)\end{array}$ & $82(4.5 \%)$ & 2 \\
\hline Copper & $\begin{array}{l}36 \\
(2.0 \%)\end{array}$ & $\begin{array}{l}72 \\
(4.0 \%)\end{array}$ & $\begin{array}{l}88 \\
(4.9 \%)\end{array}$ & $184_{(10.2 \%)}$ & 12 \\
\hline Mercury & $\begin{array}{l}38 \\
(2.1 \%)\end{array}$ & $\begin{array}{l}46 \\
(2.5 \%)\end{array}$ & $\begin{array}{l}38 \\
(2.1 \%)\end{array}$ & 112 (6.2\%) & 10 \\
\hline Cadmium & $\begin{array}{l}18 \\
(1.0 \%)\end{array}$ & $\begin{array}{l}80 \\
(4.4 \%)\end{array}$ & $\begin{array}{l}43 \\
(2.4 \%)\end{array}$ & $130(7.2 \%)$ & 11 \\
\hline Zinc & $\begin{array}{l}20 \\
(1.1 \%)\end{array}$ & $\begin{array}{l}52 \\
(2.9 \%)\end{array}$ & $\begin{array}{l}58 \\
(3.2 \%)\end{array}$ & $128(7.1 \%)$ & 2 \\
\hline Lead & $\begin{array}{l}21 \\
(1.2 \%)\end{array}$ & $\begin{array}{l}44 \\
(2.4 \%)\end{array}$ & $\begin{array}{l}86 \\
(4.8 \%)\end{array}$ & $140(7.7 \%)$ & 11 \\
\hline \multicolumn{6}{|c|}{$\begin{array}{l}\text { The number of regulated transcripts in comparison to the total number of strains }(1,870) \text {, its } \\
\text { percentage is in parentheses. }\end{array}$} \\
\hline $\begin{array}{l}\text { (*) The nur } \\
\text { more conc } \\
\text { the sum of }\end{array}$ & $\begin{array}{l}\text { er of } \\
\text { tration } \\
\text { ianscri }\end{array}$ & $\begin{array}{l}\text { ulatec } \\
\text { of me } \\
\text { fort }\end{array}$ & $\begin{array}{l}\text { transcl } \\
\text { al that } \\
\text { e C1, C. }\end{array}$ & $\begin{array}{l}\text { ts per metal considers ove } \\
\text { and } C 3 \text { concentrations. }\end{array}$ & $\begin{array}{l}\text { pping transcripts between two or } \\
\text { Thus, these numbers do not equal }\end{array}$ \\
\hline
\end{tabular}

\section{Impacts of the different metals on transcript expression}

Transcriptomic changes induced by the presence of metal were studied for the 18 synthetic samples with the 6 metals tested independently at C1, C2, and C3 concentrations. The transcriptomic changes provoked by metals at the $\mathrm{C} 2$ concentration are presented in Fig. 1. For the 1,870 strain library, more than 70,000 assays were conducted to characterize toxicity induced by metals. An assessment of transcript expression was performed to identify specific patterns related to metallic contamination. For this task, the expression of the 1,870 reporting strains was studied by PCA. The first, second and third principal components derived from the analysis represented $24.5 \%$ of the total variability (Fig. 2A). The PCA of the transcriptomic profiling showed that only 175 transcripts over the panel of 1,870 transcripts were implicated significantly in the response to metallic stress conditions (Fig. 2B; Table S1, Supplementary Information). Among them, the expression of 38 transcripts was modified by the presence of nontoxic concentrations of metal, i.e., $\mathrm{C} 1$, whereas for toxic metal concentrations, the expression of 80 and 88 transcripts was modified for $\mathrm{C} 2$ and $\mathrm{C} 3$, respectively. 
The relevance of the transcriptomic changes was investigated from a physiological viewpoint for copper, whose toxicity is well described at the transcriptomic level. The transcripts whose expression was altered by copper were associated with 3 main metabolic functions: copper metabolism, the response to oxidative stress and secondary metabolism (Table 5). Among them, transcripts of the two copper homeostasis genes cusC and cusR, which code for an efflux pump and its regulatory protein, respectively, were both activated in a concentration-dependent manner. Transcripts implicated in iron import, such as fes, cirA and fhuA, were upregulated with increasing concentration of copper. An oxidative stress response was also found with the activation of transcripts belonging to the $\mathrm{Cpx}$ and Sox regulons, as evidenced by the activation of $h t p X, p p i A$ and SoxS (Table 5; details in Table S2 in the Supplementary Information). 
Table 5

Metabolic pathways regulated by the presence of copper

\begin{tabular}{|c|c|c|c|}
\hline Function & C1 & C2 & C3 \\
\hline \multicolumn{4}{|l|}{ Copper metabolism } \\
\hline \multirow[t]{2}{*}{ Copper export } & $\operatorname{cusR}(6.2)$ & $\operatorname{cusR}(8.0)$ & $\operatorname{cusR}(28.5)$ \\
\hline & & $\operatorname{cusC}(21.5)$ & $\operatorname{cusC}(47.5)$ \\
\hline Iron homeostasis & fes (16.8) & fes (4.5) & fes (13.0) \\
\hline \multirow[t]{2}{*}{ Iron import } & $\operatorname{cirA}(3.8)$ & $y q j H(9.17)$ & fhuA (2.2) \\
\hline & & fecA (4.0) & fhuF (3.3) \\
\hline \multicolumn{4}{|l|}{ Oxidative stress } \\
\hline \multirow[t]{3}{*}{$c p x$ regulon } & & $h t p X(8.2)$ & \\
\hline & & $m r a Z(5.0)$ & \\
\hline & & ppiA (4.3) & \\
\hline \multirow[t]{3}{*}{ sox regulon } & & & $\operatorname{fpr}(16.1)$ \\
\hline & & & $\operatorname{sod} A(42.9)$ \\
\hline & & & $\operatorname{soxS}(4.6)$ \\
\hline \multirow[t]{2}{*}{ Flagellar biosynthesis } & & & $\operatorname{flgM}(2.4)$ \\
\hline & & & flic (8.4) \\
\hline \multicolumn{4}{|l|}{ Secondary metabolism } \\
\hline Polysaccharides & $g \lg B(5.4)$ & & \\
\hline Fatty acids & fadE (6.0) & $f a b B(3.3)$ & \\
\hline Amino acids & & $\arg A(3.0)$ & \\
\hline Coenzymes & & & metK (0.24) \\
\hline
\end{tabular}

An FDA was carried out to model the metallic contamination in samples, with the subset of 175 transcripts considered relevant in the detection of metals (Fig. 2C). The FDA allows prediction of metallic contamination at C1, C2 and C3 concentrations in a sample according to its transcriptomic fingerprint with confidence levels of $98 \%, 98 \%$ and $93 \%$, respectively. The results obtained by the FDA confirmed the relevance of the use of the transcriptomic pattern for the detection of metallic contamination in synthetic matrices.

Application of transcriptomic profiling to identify metal toxicity in complex samples

Loading [MathJax]/jax/output/CommonHTML/fonts/TeX/fontdata.js

Page 12/25 
The validity of the approach was investigated by assessing toxicity in complex samples with the use of bioassays. These bioassays were used to characterize the overall toxicity of the samples with E. coli DH1 pBtaclux and the toxicity related to metals by the transcriptomic fingerprint approach. A validation step was carried out by quantifying the overall content and the bioavailable fraction of metals by ICP-MS and the use of bioluminescent reporter strains. Assays were carried out directly on liquid matrices and on leachates for solid matrices. Toxicity was found in 11 matrices among the 17 tested and ranged from weak inhibition of approximately $20 \%$ to a high toxicity of $99 \%$. In the cases of toxicity above $25 \%$, samples were diluted for the analyses (Table 6). Transcriptomic fingerprints were used to identify metallic contamination and toxicity among the samples. For this purpose, the expression of the metal fingerprint composed of 175 transcripts was studied through dedicated statistical analysis, and transcript expression patterns were established as presented in Fig. 3.

Table 6: Characterization of the metallic contamination in complex samples and its related toxicity: Slu-1 corresponds to a contaminated sludge reference (Sigma Aldrich, Fr), and Slu-2 corresponds to sludge sampled from an industrial chemical waste treatment plant (courtesy of Solvay, Tavaux, Fr). leff-1, -2 , and -3 are industrial effluents, specifically from the inlet, treatment and outlet areas of an industrial chemical waste treatment plant (courtesy of Solvay, Tavaux, Fr); WS-1 to WS-4 are 4 uncharacterized wood samples in which WS-1 and WS-2 have been artificially contaminated by an unknown cocktail of metals (courtesy of the Ecole Supérieure du Bois Nantes, Fr). So-1 and -2 are 2 environmental soil samples contaminated by anthropic activities (courtesy of Greenation society, Fr), while Riv-1 to Riv-4 correspond to water samples from the Yon river (Pays de la Loire, Fr). Riv-1 is the bulk sample, Riv-2 is the river sample spiked with a known concentration of copper, and Riv-3 and -4 are the river sample spiked with known mixes of copper and cadmium.

\begin{tabular}{|c|c|c|c|c|c|c|c|c|c|c|c|c|c|c|c|c|c|}
\hline \multirow[b]{3}{*}{ Complex matrices } & \multicolumn{9}{|c|}{ Industrial origin } & \multicolumn{8}{|c|}{ Envir onmentsl origin } \\
\hline & \multicolumn{2}{|c|}{ Sludge } & \multicolumn{3}{|c|}{ Effuemt } & \multicolumn{4}{|c|}{ Wood } & \multicolumn{2}{|c|}{ Soil } & \multicolumn{2}{|c|}{ Sedment } & \multicolumn{4}{|c|}{ Rives } \\
\hline & Slu-1 & Slu 2 & ketll-1 & kefl2 & ketf 3 & WS-1 & WS 2 & WS 3 & WS-4 & So-1 & $\mathrm{So} 2$ & Sed 1 & Sed 2 & Riv 1 & Riv2 & Riv3 & $\operatorname{Riv} 4$ \\
\hline \begin{tabular}{|l|} 
Whole taxioly \\
\end{tabular} & $77 \%$ & $0 \%$ & $99 \%$ & $0 \%$ & $0 \%$ & $23 \%$ & $40 \%$ & $52 \%$ & $95 \%$ & $0 \%$ & $0 \%$ & $40 \%$ & $25 \%$ & $0 \%$ & $60 \%$ & $78 \%$ & $90 \%$ \\
\hline \begin{tabular}{|l|} 
Metal prasance \\
\end{tabular} & + & - & - & - & - & - & - & - & - & - & - & - & - & - & + & + & + \\
\hline Metal taxicity & $\mathrm{C} 2$ & & & & & & & & & & & & & & $\mathrm{C} 2$ & $\mathrm{C} 3$ & $\mathrm{C}_{3}$ \\
\hline \multicolumn{18}{|c|}{ Total fraction of metal } \\
\hline Cul & 5309.0 & 0.5 & 10.2 & 3.3 & 0.3 & $30.1^{*}$ & $100.6^{*}$ & nd. & ned & 3.6 & 3.6 & 0.7 & 0.2 & ne. & 950.0 & 151.5 & 303.0 \\
\hline As & nd. & ne. & 0.2 & na. & nd. & $6.1^{*}$ & ne & ne & ne & na & ne. & 0.4 & 0.1 & ne. & ne & nd & ne \\
\hline $\mathrm{Hg}$ & na. & ne. & ne. & na & nd. & ne. & ne. & ne. & na. & na & na & ne. & ne. & ne. & ne. & na & ne. \\
\hline$c o$ & ne. & na. & ne. & na & ne. & no. & $30.2^{*}$ & ned & ne & na & ne. & no. & na & ne. & na. & 68.3 & 132.5 \\
\hline $2 n$ & 0.2 & 0.2 & 0.4 & 0.1 & ne. & na. & $3195.2^{*}$ & ne. & no. & 7.5 & 8.4 & 0.2 & 0.4 & ne. & ne. & na & na \\
\hline $\mathrm{Fo}$ & 171.3 & 0.2 & ned & ne & nd. & $49.4^{\circ}$ & $n d$ & ned & no. & 0.9 & 12 & ned & 0.1 & no. & ne. & nd & ne. \\
\hline $\mathrm{Cr}$ & nd. & nd. & ne. & nd. & nd. & $43.3^{*}$ & ne. & nd & ne. & na & ne. & ned & nd & ne. & ne. & na & ned \\
\hline \multicolumn{18}{|c|}{ Bloala lable faction of metal } \\
\hline Cu & $125-1250$ & ned & ned & nd. & nd. & nd. & $n d$. & nd. & ne. & nd & nd. & ned & nd. & ne & $250-25000$ & $125-1250$ & $250-2500$ \\
\hline As & ne. & na. & ned & ne. & ne. & nd & ne. & ne. & ne. & na & ne. & ne. & ne. & no. & nd. & nd & ne. \\
\hline $\mathrm{Hg}$ & nd. & ne. & ned & nd & ne. & ne. & ned & ne & ne. & na & ne. & nd. & ne & ne. & ne. & n.d & ned \\
\hline col & nd. & ne. & ned & nd. & nd. & nd. & ned & no. & ne. & nd & ne. & ne. & nd. & no. & ne. & 1.25 .250 & $2.5-500$ \\
\hline
\end{tabular}

"Asterisk $s$ corresponos to metallic concentration measured in the natlie sample, before the leaching step. Due to technical olficultes concentrations $n$ the leachate vas not meas urable for these samples.

Toxicity assessment performed on sludge Slu-1, which corresponded to a reference sludge, showed an inhibition of $77 \%$ with the E. coli DH1 pBtaclux reporter, whereas sludge Slu-2, which corresponded to a sample freshly collected from an industrial treatment plant (Solvay Tavaux, Fr), did not show any toxicity by the bacterial bioassay (Table 6). To characterize the toxicity found in Slu-1, transcriptomic fingerprinting analysis was carried out, and the impact on the expression of transcripts was compared to Loading [MathJax]/jax/output/CommonHTML/fonts/TeX/fontdata.js 3). The analysis of the fingerprints indicated 
that metallic contamination was present in the sample and that the metals exerted toxicity reaching the LOEC level (i.e., C2). To validate this result, the total fractions of metals were confirmed through analytical procedures, which showed that 5,309 $\mu \mathrm{M}$ copper was present, but only 125-1,250 $\mu \mathrm{M}$ was bioavailable according to the bioluminescent reporters. The bioavailable fraction found in the sample is in the range of $\mathrm{C} 2$ toxicity for copper, which is in accordance with the results given by the transcriptomic approach.

The industrial effluents came from an industrial treatment plant (Solvay Tavaux, Fr). They were collected at the inlet, treatment and outlet areas of the treatment plant and identified as leff- 1 to leff-3, respectively. leff-1 presented high toxicity, whereas leff-2 and leff-3 were not toxic to $E$. coli DH1 pBtaclux (Table 6). Regarding metallic contamination, leff- 1 was diluted until its toxicity reached $\mathrm{EC}_{25}$ for transcriptomic fingerprint analysis. The FDA model indicated the presence of metal in leff-1, but the concentrations of the metals characterized in this study was not, a priori, responsible for the toxicity found in this sample (Table 6). Chemical analyses revealed the presence of $10.2 \mu \mathrm{M}$ copper as the total fraction, whereas its bioavailable fraction remained undetectable by bioluminescent bacteria. Consequently, the metals present did not appear to be the cause of the toxicity observed in leff- 1 .

Wood samples (WSs) were 2 wood waste samples contaminated by metals (WS-1, WS-2) and 2 wood samples in which no metal contaminants were reported (WS-3, WS-4). All the samples were lixiviated, and their leachates were assayed for toxicity prior to their analysis for metals. WS-1, WS-2, WS-3 and WS-4 showed toxicities of $23 \%, 40 \%, 52 \%$ and $95 \%$, respectively (Table 6; Fig. 3 ). The fingerprint analysis indicated that toxicity found in the samples was not associated with metals for all the WS samples. These results were confirmed by bioluminescent strain-based bioassays reporting that no bioavailable metals were in the 4 WSs.

Soil matrices So-1 and So-2 showed no toxicity and no significant metallic contamination. Similarly, for Sed-1 and Sed-2, toxicity reported by E. coli DH1 pBtaclux was not linked to the presence of the relevant concentrations of metals, as indicated by the transcriptomic analysis and confirmed by the bioluminescent strains (Table 6).

River matrices corresponded to a unique environmental sample (Riv-1) to which different metal contaminants were added to generate Riv-2 to Riv-4 samples. No toxicity and no relevant bioavailable metals were found in the Riv-1 matrix for which no metallic contaminant was added. For Riv-2 to Riv-4, the samples were spiked with copper (Riv-2) or both copper and cadmium (Riv-3 and Riv-4). The toxicity of Riv-2, which was contaminated with $950 \mu \mathrm{M}$ copper, as determined by E. coli DH1 pBtaclux resulted in an inhibition of $60 \%$ bioluminescence, which is in accordance with the results found previously in this study regarding the establishment of the $\mathrm{C} 2$ concentration for copper. Transcriptomic fingerprint analysis was performed on the sample after its dilution to $25 \%$ toxicity (Table 6). Prediction of metallic contamination using the FDA model indicated metallic contamination at $\mathrm{C} 2$, which is in accordance with the concentration of bioavailable copper found with the bioluminescent reporters (Fig. 2). The river samples contaminated by a mixture of 2 metals exhibited a higher toxicity. The Riv-3 and Riv- 4 samples, whinh wanrn nantaminntad with nnnnar and nadmium at $151.5 \mu \mathrm{M}$ and $66.3 \mu \mathrm{M}$ for Riv-3 and $303 \mu \mathrm{M}$ and Loading [MathJax]/jax/output/CommonHTML/fonts/TeX/fontdata.js 
$132.5 \mu \mathrm{M}$ for Riv-4, respectively, showed overall toxicities of $78 \%$ and $90 \%$ (Fig. 3; Table 6). The samples were diluted until the effective toxicity reached $25 \%$ for the transcriptomic analysis. Prediction of the metallic contamination of Riv-3 and Riv-4 indicated C3 contamination, for which copper and cadmium were found to be bioavailable using bioluminescent reporters. Transcriptomic analysis makes it possible to consider the whole toxicity resulting from metallic contamination regardless of whether the source of the toxicity is a single contaminant or a mixture of metals.

\section{Discussion}

Assessing the ecotoxicological impact of contaminants is complex in natural samples because they are diverse and constantly changing and mixing. Traditional tools used to assess toxicity include physicochemical analyses and biological analyses that use reporter bacteria. Many bacterial reporters have been developed for metal analyses. However, although these techniques are specific and allow the quantification of a given metal, they are inefficient and costly to perform if there is no initial indication of the nature of the pollution present in the sample. To address this issue, this study developed a screening method that provides information about metal toxicity in unknown complex samples. Information given by this methodology aims to complement that obtained by the existing tools available to industry and ecotoxicologists to ensure safety management.

In this study, the toxicity of 6 metals was characterized with E. coli before transcriptomic studies were performed. The toxicity of the different metals aligned with literature results for E. coli K12 MG1655 (Jouanneau et al., 2011). The approach was validated by a comparison between the transcriptomic responses found for metal contamination and those in the literature; detailed information is presented in the Supplemental Section (Table S2). This analysis validates the biological relevance of using the transcriptomic method to detect toxicity.

The second part of our study developed a screening methodology for the analysis of complex samples to address a concept proposed in the literature for synthetic samples (Elad et al., 2013; 2015). This development used statistical tools to exploit the information given by the transcriptomic fingerprints. Statistical analysis allowed us to describe and explain the variations in transcript expression that were linked to metal contamination. In this way, a relevant core of 175 transcripts was found to be sufficient to characterize the presence or absence of a metal and to quantify its relative toxicity. Similar statistical approaches have already been successfully carried out to characterize the presence of contaminants in mussels (André and Gagné, 2020).

The panel of 175 transcriptomic reporters used in this study can identify the presence of metals and their associated toxicity in unknown samples. This fingerprinting method complements traditional analytical standard methods and bioassays reported in the literature (Charrier et al., 2011; Jounneau et al., 2011). As its main advantage, the method enables the prioritization of samples according to their metallic status and the associated toxicity. In an industrial context, this type of screening can be employed since autnmation nnnortunitioc san ho onvicanod in tho ninotting/incubation/fluorescence reading steps. In our Loading [MathJax]/jax/output/CommonHTML/fonts/TeX/fontdata.js 
study, the use of screening microplates that had been stored frozen prior to their use illustrates the possibility of deploying the methodology in a ready-to-use bioassay directly on an industrial site. This strategy limits the associated labour due to the preparation of the transcriptomic library and offers an interesting way to reduce production cost. In summary, the transcriptomic profiling screening method is a realistic opportunity to save costs associated with ecotoxicity assessments. The screening method allows a characterization of the relevant matrices that were contaminated by metals and that require a complete metal quantification through regulatory analyses (from 35 to 100 euros per metal analysed) (Fig. 4).

Two main perspectives of development increase the relevance of this method. The first issue highlights the scope of the analysis, which provides information about different contaminants by the development of complementary fingerprints. Work performed in the literature opened the way with the identification of fingerprints targeting new contaminants. The next step in this development should be the identification of a relevant pattern of transcripts that exhibit specificity for a toxicant in complex matrices despite environmental disturbances. The second issue is the identification of specific contaminants. In this sense, the use of transcriptomic fingerprints should complement traditional bioassays, but this approach requires a dedicated experimental plan to ensure relevant significance with regard to several contaminants that are encountered in complex matrices.

\section{Conclusion}

The use of transcriptomic fingerprints to characterize toxicity elucidates the impact of contaminants on living organisms. The aim of this study was to adapt the use of a transcriptomic database to complex samples to identify metallic contamination. A set of 175 reporting strains was constituted to establish the metallic status of complex samples, including industrial wastes and environmental samples containing metals, whether at toxic concentrations or below. The statistical approach allows quantification of the toxicities associated with the metals in samples and provides an interesting screening tool for an environmental assessor to determine the role of metals in the toxicity of a matrix. This study partially overcomes the bottleneck to the transfer of methodologies established for the detection of a contaminant in a synthetic sample to their real applications in environmental samples and waste. According to the large variety of fingerprints offered by the transcriptomic assays, the development of this approach can

be interesting for the detection of a wide variety of pollutants in complex matrices such as waste or the environment.

\section{Declarations}

\section{Ethics approval and consent to participate}

Not applicable

\section{Consent for publication}


Not applicable

\section{Availability of data and materials}

The datasets used and/or analysed during the current study are available from the corresponding author on reasonable request.

\section{Competing interests}

The authors declare that they have no competing interests

\section{Funding}

The authors thank their financial support (Ville de la Roche sur Yon, Conseil Général de Vendée, Conseil régional des Pays de la Loire and the French Ministry of Research).

\section{Authors' contributions}

$\mathrm{CM}$ and $\mathrm{HA}$ contributed equally to the preparation of the manuscript. The authors CM and HA analysed and interpreted transcriptomic data. The authors AA and CC contributed to the statistical analyses. The authors SJ, GT and MJDs contributed to the bioassay expertise. All authors read, expertise and approved the final manuscript.

\section{Acknowledgments}

We thank Josselin Bobet from the Solvay company for providing industrial treatment water samples.

\section{References}

André C, Gagné F (2020) The comparative toxicity of rainfall overflows and a municipal effluent plume in Elliptio complanata using a novel qPCR array approach. Comp Biochem Phys C. 232:108760.

Belkin S (2003), Microbial whole-cell sensing systems of environmental pollutants. Curr Opin Microbiol 6(3):206-212. https://doi.org/10.1016/S1369-5274(03)00059-6.

Ben-Israel O, Ben-Israel H, Ulitzur S (1998) Identification and quantification of toxic chemicals by use of Escherichia coli carrying lux genes fused to stress promoters. Appl Environ Microbiol 64(11):4346-4352.

Cedergreen N (2014) Quantifying synergy: A systematic review of mixture toxicity studies within environmental toxicology. PLOS One 9(5)e96580.

Charrier T, Durand MJ, Jouanneau S, Dion M, Pernetti M, Poncelet D, Thouand G (2011) A multi-channel bioluminescent bacterial biosensor for the on-line detection of metals and toxicity. Part I: Design and optimization of bioluminescent bacterial strains. Anal BioanalChem 400(4):1051-1060. 
Cordella CBY, Bertrand D (2014) SAISIR: A new general chemometric toolbox. Trends Analyt Chem 54:7582. https://doi.org/10.1016/j.trac.2013.10.009.

Council Regulation (EC) No 735/2017 of 14 February 2017 amending, for the purpose of its adaptation to technical progress, the Annex to Regulation (EC) No 440/2008 laying down test methods pursuant to Regulation (EC) No 1907/2006 of the European Parliament and of the Council on the Registration, Evaluation, Authorisation and Restriction of Chemicals (REACH). Available at https://eurlex.europa.eu/legal-content/en/TXT/PDF/?uri=CELEX:32017R0735\&from=IT

Council Regulation (EC) No 440/2008 of 30 May 2008 laying down test methods pursuant to Regulation (EC) No 1907/2006 of the European Parliament and of the Council on the Registration, Evaluation, Authorisation and Restriction of Chemicals (REACH) Available at http://data.europa.eu/eli/reg/2008/440/oj

D’Souza SF (2001) Microbial biosensors.BiosensBioelectron 16(6):337-353. https://doi.org/10.1016/S0956-5663(01)00125-7.

Directive (EC) 1999/45/EC of the European Parliament and of the Council of 31 May 1999 concerning the approximation of the laws, regulations and administrative provisions of the Member States relating to the classification, packaging and labelling of dangerous preparations. Available at https://eurlex.europa.eu/legal-content/EN/TXT/PDF/?uri=CELEX:31999L0045\&from=FR

Directive (EC) 2008/98/EC of the European Parliament and of the Council of 19 November 2008 on waste and repealing certain Directives. Available at https://eur-lex.europa.eu/eli/dir/2008/98/oj

Elad T, Belkin S (2013) Broad spectrum detection and "barcoding" of water pollutants by a genome-wide bacterial sensor array. Water Res 47(11):3782-3790. https://doi.org/10.1016/j.watres.2013.04.011.

Elad T, Seo HB, Belkin S, Gu MB (2015) High-throughput prescreening of pharmaceuticals using a genome-wide bacterial bioreporter array. BiosensBioelectron 68:699-704. https://doi.org/10.1016/j.bios.2015.01.067.

Eurostat (2020) Waste statistics, source: Statistics Explained 08/01/2020 https://ec.europa.eu/eurostat/statistics-explained/index.php?title=Waste_statistics\#Waste_treatment

Foucault Y, Durand M-J, Tack K, Schreck E, Geret F, Leveque T, Pradere P, Goix S, Dumat C (2013) Use of ecotoxicity test and ecoscores to improve the management of polluted soils: case of a secondary lead smelter plant. J Hazard Mat 246-247:291-299 https://doi.org/10.1016/j.jhazmat.2012.12.042

Gueuné H, Thouand G, Durand MJ (2009) A new bioassay for the inspection and identification of TBTcontaining antifouling paint. Mar Pollut Bull 58(11):1734-1738. https://doi.org/10.1016/j.marpolbul.2009.09.012. 
Hennebert P, Rebischung F, Langeron P (2013) Eu waste hazardousness assessment - proposition of methods. 14. International Waste Management and Landfill Symposium (Sardinia 2013). Cagliari, Italy. pp.NC. ineris-00976249.

Hua A, Gueuné H, Cregut M, Thouand G, Durand MJ (2016) Development of a bacterial bioassay for atrazine and cyanuric acid detection. Front Microbiol 6:211. http://dx.doi.org/10.3389/fmicb.2015.00211

Ivask A, Virta M, Kahru A (2002) Construction and use of specific luminescent recombinant bacterial sensors for the assessment of bioavailable fraction of Cadmium, Zinc, Mercury and Chromium in the soil. Soil BiolBiochem 34(10):1439-1447. https://doi.org/10.1016/S0038-0717(02)00088-3

Jouanneau S, Durand MJ, Courcoux P, Blusseau T, Thouand G (2011) Improvement of the identification of four heavy metals in environmental samples by using predictive decision tree models coupled with a set of five bioluminescent bacteria. Environ SciTechnol 45(7):2925-2931.

https://doi.org/10.1021/es1031757.

Kaag NHB, Foekema EM, Scholten MC Th (1998) Ecotoxicity of contaminated sediments, a matter of bioavailability.WatSci Tech 37(6-7):225-231.

Martín-Betancor K, Rodea-Palomares I, Muñoz-Martin MA, Leganés F, Fernández-Piñas F (2015) Construction of a self-luminescent cyanobactorial bioreporter that detects a broad range of bioavailable heavy metals in aquatic environments. Front. Microbiol. (6)186..

https://doi.org/10.3389/fmicb.2015.00186

Pandard P, Devillers J, Charissou AM, Poulsen V, Jourdain MJ, Férard JF, Grand C, Bispo A (2006) Selecting a battery of bioassays for ecotoxicological characterization of wastes. Sci. Total Environ. 363:114-125.

Pandard P, Römbke J (2013) Proposal for a "harmonized" strategy for the assessment of the HP 14 property Integr Environ Asses 9(4):665-672. https://doi.org/doi:10.1002/ieam.1447

Su G, Zhang X, Liu H, Giesy JP, Lam MHW, Lam PKS, Siddiqui MA, Musarrat J, Al-Khedhairy A, Yu H (2011) Toxicogenomic mechanisms of 6-HO-BDE-47, 6-MeO-BDE-47, and BDE-47 in E. coli. Environ SciTechnol 46(2):1185-1191. https://doi.org/10.1021/es203212w.

Su G, Zhang X, Raine JC, Xing L, Higley E, Hecker M, Giesy JP, Yu H (2013) Mechanisms of toxicity of triphenyltin chloride (TPTC) determined by a live cell reporter array. Environ SciPollut Res Int 20(2):803811. https://doi.org/10.1007/s11356-012-1280-7

Trang PTK, Berg M, Viet PH, Mui NV, van der Meer JR (2005) Bacterial bioassay for rapid and accurate analysis of arsenic in highly variable groundwater samples. Environ SciTechnol 39(19):7625-7630. https://doi.org/10.1021/es050992e. 
van der Meer JR, Belkin S (2010) Where microbiology meets microengineering: Design and applications of reporter bacteria. Nat Rev Microbiol 8(7):511-522.

Vig K, Megharaj M, Sethunathan N, Naidu R (2003) Bioavailability and toxicity of cadmium to microorganisms and their activities in soil: a review. Adv Environ Res 8:121-135.

https://doi.org/doi:10.1016/S1093-0191(02)00135-1

Wong YS, Tam NFY, Lau PS, Xue XZ (1995) The toxicity of marine sediments in Victoria Harbour, Hong Kong. Mar Pollut Bull. 31(4):464-470. https://doi.org/10.1016/0025-326X(96)81927-8.

Xu T, Close DM, Sayler GS, Ripp S (2013) Genetically modified whole-cell bioreporters for environmental assessment. Ecol Indic 28:125-141. https://doi.org/10.1016/j.ecolind.2012.01.020.

Zaslaver A, Bren A, Ronen M, Itzkovitz S, Kikoin I, Shavit S, Liebermeister W, Surette MG, Alon U (2006) A comprehensive library of fluorescent transcriptional reporters for Escherichia coli. Nat Methods 3(8):623628. https://doi.org/10.1038/nmeth895.

Zhang X, Wiseman S, Yu H, Liu H, Giesy JP, Hecker M (2011) Assessing the toxicity of naphthenic acids using a microbial genome wide live cell reporter array system. Environ SciTechnol 45(5):1984-1991. https://doi.org/10.1021/es1032579.

\section{Figures}


A
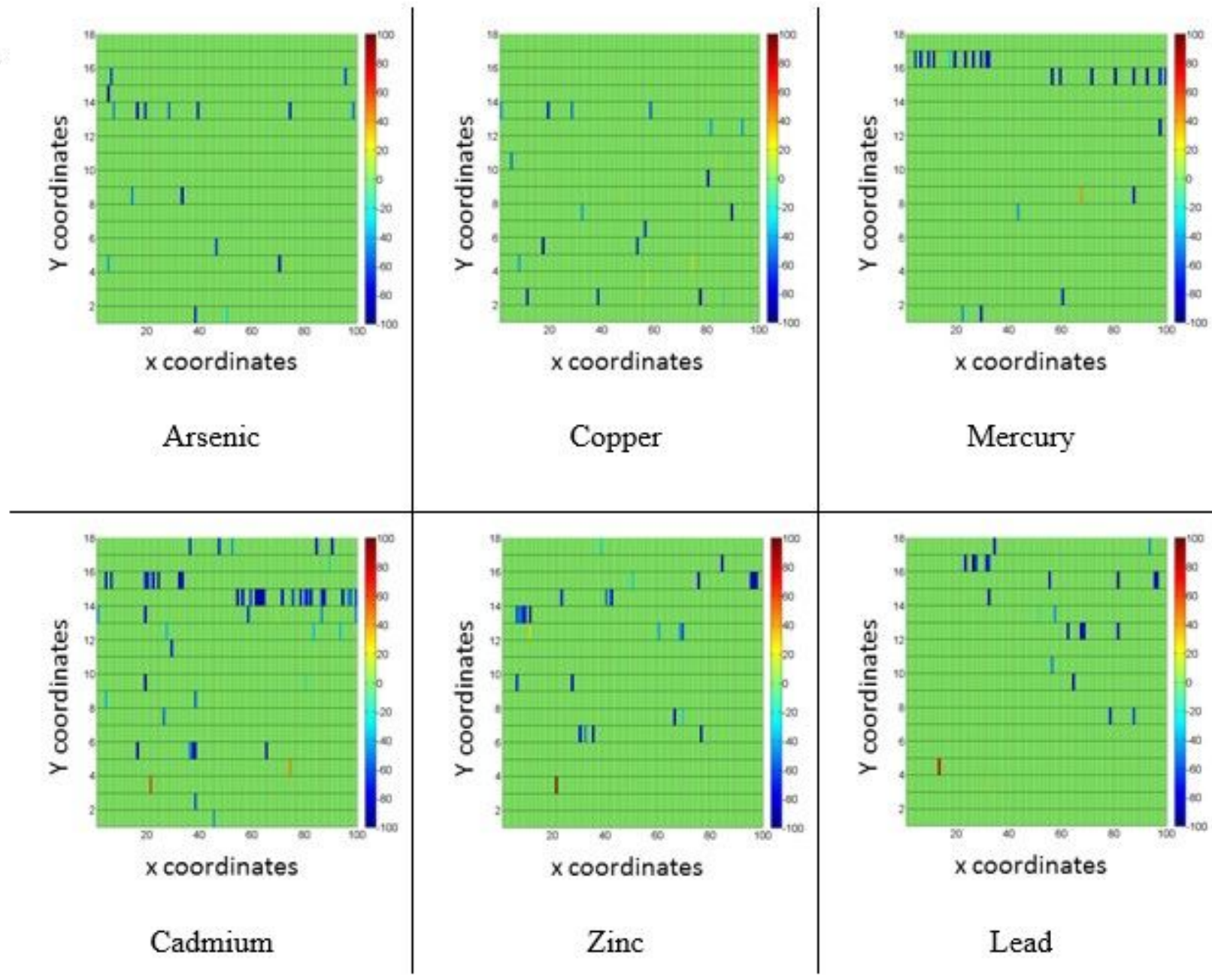

Mercury

B

\begin{tabular}{c|cccccc} 
Metal & $\begin{array}{c}\text { Arsenic } \\
(\mathbf{3 2})\end{array}$ & $\begin{array}{c}\text { Copper } \\
(\mathbf{7 2})\end{array}$ & $\begin{array}{c}\text { Mercury } \\
(\mathbf{4 6})\end{array}$ & $\begin{array}{c}\text { Cadmium } \\
\mathbf{( 8 0 )}\end{array}$ & $\begin{array}{c}\text { Zinc } \\
(\mathbf{5 2})\end{array}$ & $\begin{array}{c}\text { Lead } \\
(\mathbf{4 4})\end{array}$ \\
\hline Arsenic (32) & $\mathrm{x}$ & 8 & 8 & 5 & 5 & 1 \\
Copper (72) & & $\mathrm{x}$ & 11 & 14 & 5 & 3 \\
Mercury (46) & & & $\mathrm{x}$ & 11 & 13 & 2 \\
Cadmium (80) & & & & $\mathrm{x}$ & 10 & 3 \\
Zinc (52) & & & & & $\mathrm{x}$ & 4 \\
Lead (44) & & & & & & $\mathrm{x}$
\end{tabular}

\section{Figure 1}

Transcriptomic regulation in response to metals at the $\mathrm{C} 2$ concentrations. (A) Transcriptomic fingerprints induced by the presence of the dedicated metal with IndRF values of $[-100,0]$ for repressed transcripts, 0 for unregulated transcripts and $[0,100]$ for activated transcripts. The results presented are the averages of two independent experiments. (B) Number of transcripts regulated in common between the tested metals at $\mathrm{C} 2$ concentrations. The number of transcripts regulated by the metal at $\mathrm{C} 2$ is shown in parentheses. 

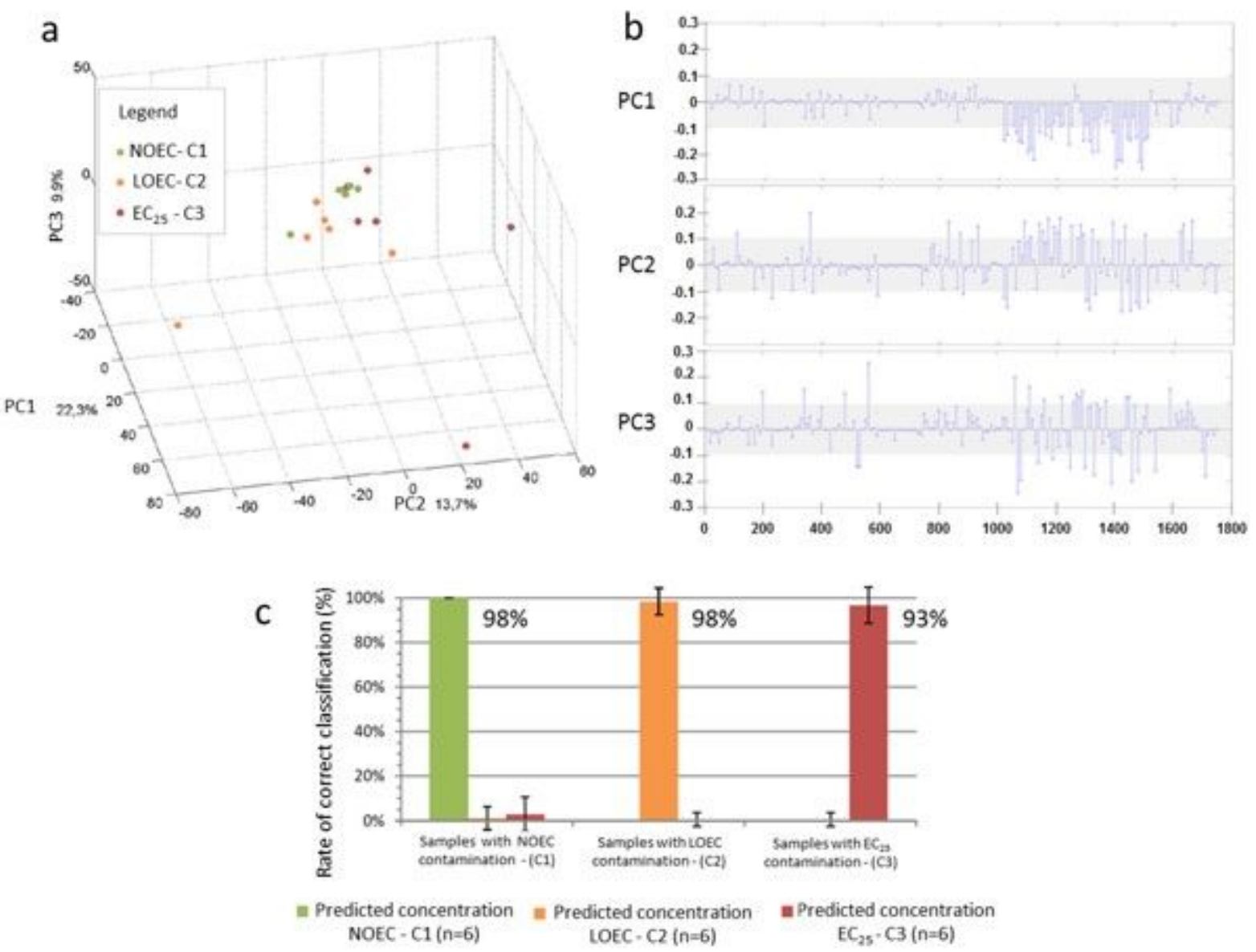

\section{Figure 2}

Principal component analysis of synthetic samples based on the global panel of 1870 transcriptomic reporters according to their metallic contamination $(A)$ and the associated loadings presenting the contribution to the first 3 axes of the PCA. The shaded space corresponds to the pool of transcripts that are not relevant for metal detection (B). Factorial discriminant analysis performed on the restricted panel of 175 transcriptomic reporters that are relevant for the detection of metallic contamination (C). The confidence of the analysis ranged from $93 \%$ to $98 \%$. 


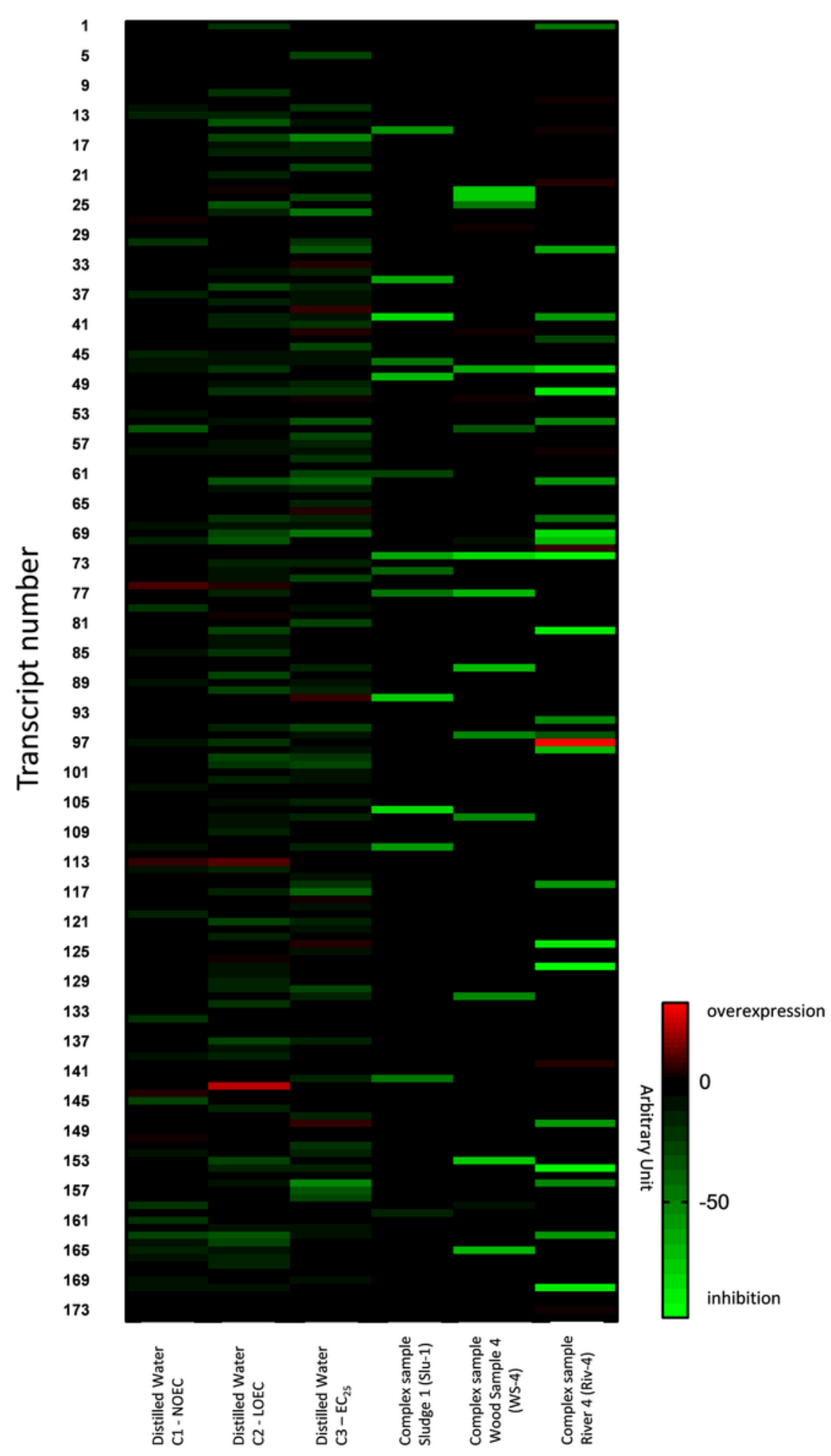

\section{Figure 3}

Response of the 175 transcripts implicated in the detection of metallic contamination, i.e., general fingerprints for $\mathrm{C} 1, \mathrm{C} 2$, and $\mathrm{C} 3$ from the synthetic matrix and 3 transcriptomic fingerprints given from complex samples (Slu-1, WS-4 and Riv-4). The names of the transcripts are reported in Table S1 in the Supplemental Section. 

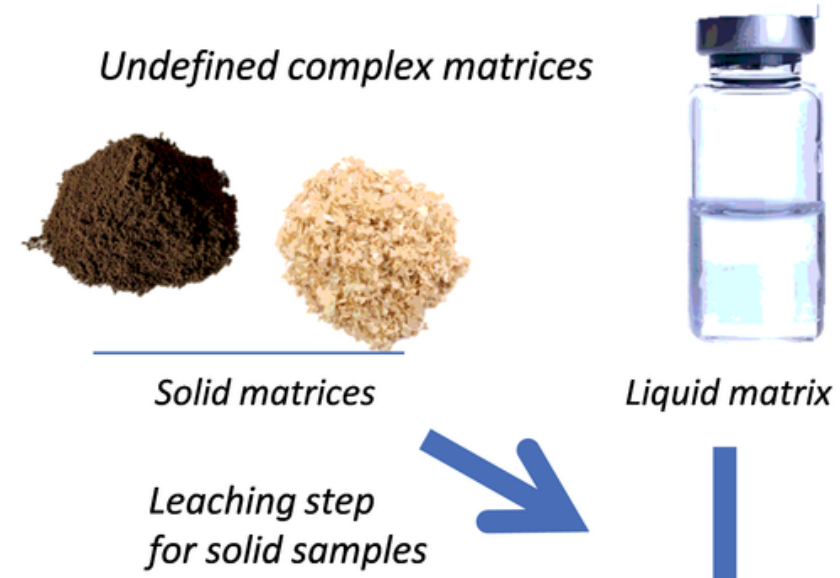

Liquid matrix

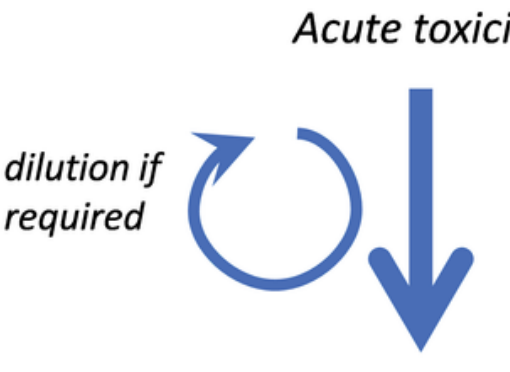

\section{Metal Transcript fingerprints}
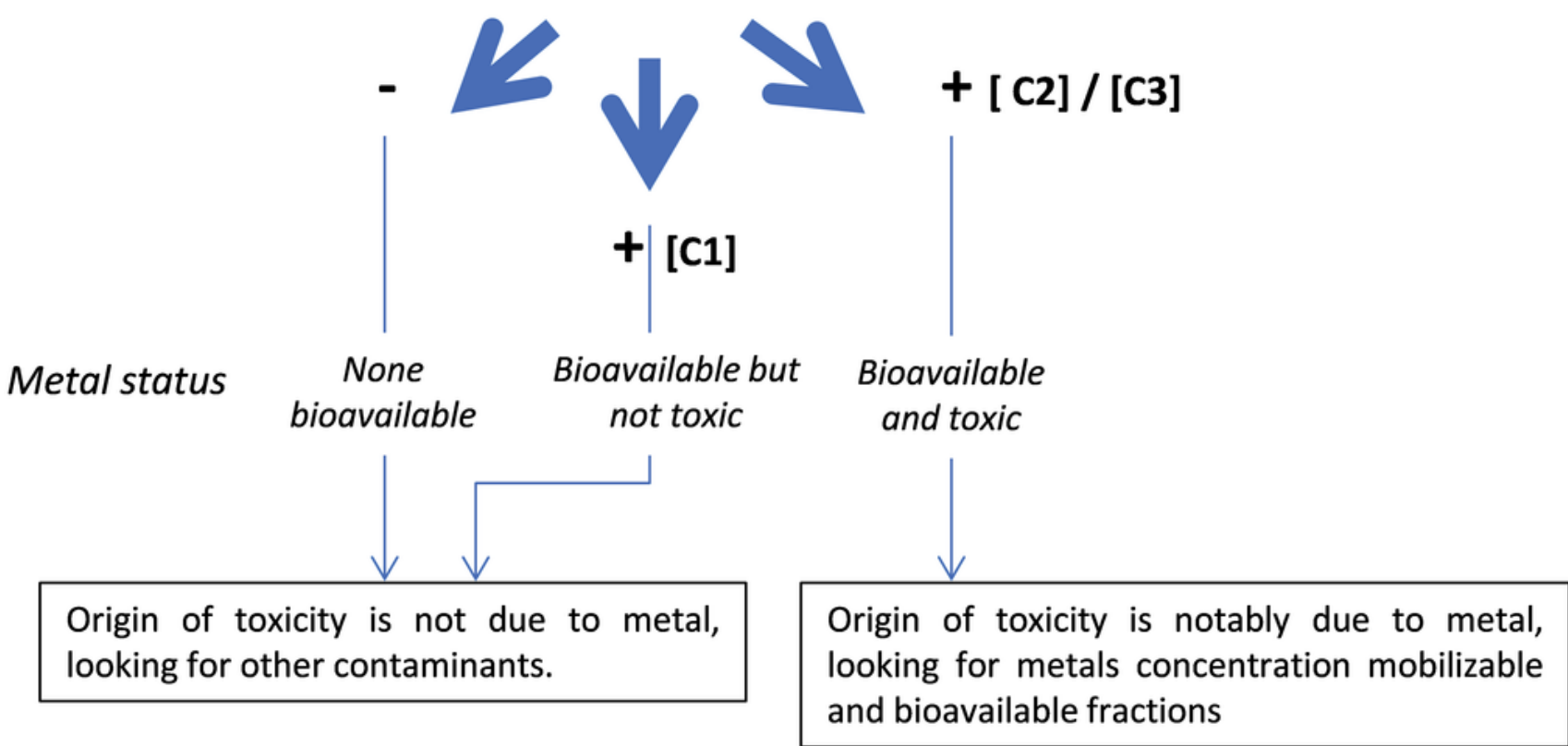

Figure 4

Schematic role of the testing procedure in the characterization of unknown complex samples

\section{Supplementary Files}


- SupplementallnformationHuaetal2020avtAJE.docx 